\title{
Aerobic methanotrophy within the pelagic redox-zone of the Gotland Deep (central Baltic Sea)
}

\author{
O. Schmale ${ }^{1}$, M. Blumenberg ${ }^{2}$, K. Kießlich ${ }^{1}$, G. Jakobs ${ }^{1}$, C. Berndmeyer ${ }^{2}$, M. Labrenz ${ }^{1}$, V. Thiel ${ }^{2}$, and G. Rehder ${ }^{1}$ \\ ${ }^{1}$ Leibniz Institute for Baltic Sea Research Warnemünde (IOW), Rostock, Germany \\ ${ }^{2}$ Geobiology Group, Geoscience Centre, Georg-August-University Göttingen, Göttingen, Germany
}

Correspondence to: O. Schmale (oliver.schmale@io-warnemuende.de)

Received: 25 June 2012 - Published in Biogeosciences Discuss.: 20 July 2012

Revised: 15 November 2012 - Accepted: 19 November 2012 - Published: 5 December 2012

\begin{abstract}
Water column samples taken in summer 2008 from the stratified Gotland Deep (central Baltic Sea) showed a strong gradient in dissolved methane concentrations from high values in the saline deep water (max. $504 \mathrm{nM}$ ) to low concentrations in the less dense, brackish surface water (about $4 \mathrm{nM}$ ). The steep methane-gradient (between 115 and $135 \mathrm{~m}$ water depth) within the redox-zone, which separates the anoxic deep part from the oxygenated surface water (oxygen concentration $0-0.8 \mathrm{mLL}^{-1}$ ), implies a methane consumption rate of $0.28 \mathrm{nMd}^{-1}$. The process of microbial methane oxidation within this zone was evident by a shift of the stable carbon isotope ratio of methane between the bottom water $\left(\delta^{13} \mathrm{CCH}_{4}=-82.4 \%\right.$ o $)$ and the redoxzone $\left(\delta^{13} \mathrm{CCH}_{4}=-38.7 \%\right.$ o). Water column samples between 80 and $119 \mathrm{~m}$ were studied to identify the microorganisms responsible for the methane turnover in that depth interval. Notably, methane monooxygenase gene expression analyses for water depths covering the whole redox-zone demonstrated that accordant methanotrophic activity was probably due to only one phylotype of the aerobic type I methanotrophic bacteria. An imprint of these organisms on the particular organic matter was revealed by distinctive lipid biomarkers showing bacteriohopanepolyols and lipid fatty acids characteristic for aerobic type I methanotrophs (e.g., 35-aminobacteriohopane-30,31,32,33,34-pentol), corroborating their role in aerobic methane oxidation in the redox-zone of the central Baltic Sea.
\end{abstract}

\section{Introduction}

Methane as an atmospheric trace gas is known to have a relevant impact on Earth's climate. Aquatic systems represent the most significant source of atmospheric methane. However, the importance of the marine system seems to be marginal (Bange et al., 1994), although enormous amounts of methane are formed in marine sediments (Reeburgh, 2007). One effective mechanism that is limiting the flux of methane from the sedimentary reservoir into the atmosphere is the microbial oxidation of methane in the sediment and the water column (Reeburgh, 2007). Comprehensive studies on aquatic sediments in different settings show that methane is microbially oxidized by the use of different electron acceptors, with oxygen being most important for the water column and sulfate for the sedimentary turnover (Barnes and Goldberg, 1976; Reeburgh, 1976; Hinrichs and Boetius, 2002; Reeburgh, 2007). Recently, anaerobic methane oxidation using iron, manganese and nitrite has also been reported (Beal et al., 2009; Ettwig et al., 2010). Although these processes are efficient and consume the main part of dissolved methane before it escapes from the sediment/water interface, some parts of the ocean are characterised by strongly elevated methane concentrations in the water column. This holds particularly true for stagnant, oxygen-deficient basins like the Black Sea, Cariaco Basin or central Baltic Sea (Scranton et al., 1993; Kessler et al., 2006; Schmale et al., 2010a). Compared to the number of studies on the microbial processes of methane oxidation in sediments, water column studies are scarce, and could to date just identify the oxidation of methane through oxygen and sulfate (Reeburgh, 2007 and references therein). Nevertheless, multidisciplinary studies 
in the water column of the Black Sea could impressively demonstrate that the flux of methane from the deep-water reservoir into the atmosphere is effectively buffered by the microbial oxidation of methane under anaerobic and aerobic conditions (Schouten et al., 2001; Schubert et al., 2006; Wakeham et al., 2007; Blumenberg et al., 2007; Schmale et al., 2011).

Our present investigations were carried out in the Gotland Deep in the central part of the Baltic Sea (Fig. 1). The Baltic Sea is a European semi-enclosed marginal sea characterised by limnic to brackish surface water and more saline deep and bottom water. Especially for the central deep basins of the Baltic Sea, this results in limited vertical mixing, the development of a prominent redox-zone with oxic to anoxic conditions, and the formation of stable biogeochemical zones (Nausch et al., 2008). In these basins, the stagnant deep water can only be renewed by strong temporal inflow events of saline oxygenated water from the North Sea (Reissmann et al., 2009) or by long-term vertical transport mechanisms mainly induced by bottom boundary mixing along the sloping topography (Holtermann and Umlauf, 2012). More frequent are weak inflows of North Sea water that are periodically perturbing the intermediate water column stratification and biogeochemical zones in the central basins (Matthäus et al., 2008). The Baltic Sea, like other marginal seas, is characterised by high terrestrial inputs and production rates of organic matter that are to a considerable extent accumulated and decomposed in the sediment. Under anoxic conditions, the final step of decomposition of organic matter leads to the generation of methane within the sediment. In the Baltic Sea, pore-water as well as acoustic investigations demonstrated that methane is abundant in high concentrations within the sediment and that in some regions methane is also released as free or dissolved gas into the water column (Dando et al., 1994; Piker et al., 1998; Thießen et al., 2006). Extensive water column investigations in the Baltic Sea identified the strongest methane enrichment within the stagnant anoxic water bodies of the deep basins (Gotland Deep and Landsort Deep; max. $504 \mathrm{nM}$ at $230 \mathrm{~m}$ water depth and $1058 \mathrm{nM}$ at $435 \mathrm{~m}$ water depth, respectively; Schmale et al., 2010b). In contrast, surface water methane concentrations in these areas are only slightly enriched compared to the atmospheric equilibrium, indicating an effective sink that prevents the escape of methane from the deep water into the atmosphere (Schmale et al., 2010b). However, little is as yet known about the processes that regulate the methane flux in this environment. In this paper, we use a multidisciplinary approach that combines gas chemistry, molecular biology and lipid biomarker geochemistry and present data on a microbial methane sink within the pelagic redox-zone of the Gotland Deep. Thus, this study aims to investigate whether aerobic methane oxidation also plays a role in the more dynamic and turbulent redox-zone of the central Baltic Sea.

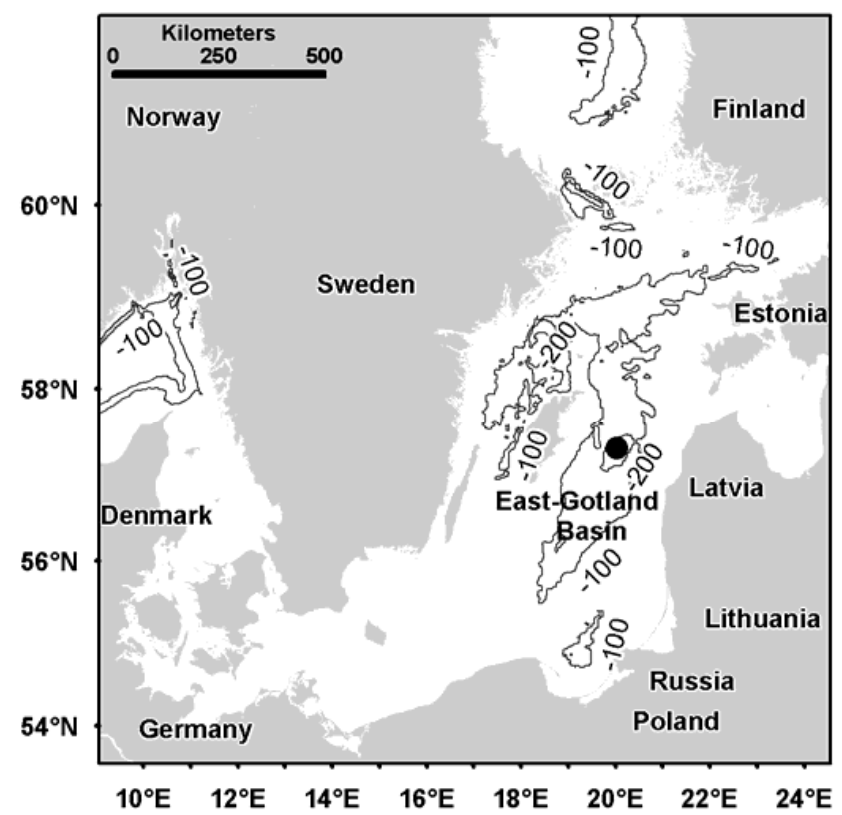

Fig. 1. The Baltic Sea and the location of the Gotland Deep. The study area is indicated with a black dot.

\section{Methods}

Samples were retrieved during a scientific cruise in summer 2008 with the German research vessel Maria S. Merian (MSM 08/3, 18 June to 18 July. The Gotland Deep $\left(57^{\circ} 18^{\prime} \mathrm{N}\right.$, $20^{\circ} 04^{\prime}$ E; Fig. 1) represents the deepest location in the eastern Gotland Basin (water depth at our water station $231 \mathrm{~m}$ ). The sampling strategy at this location was directed at (1) identifying the depth interval of aerobic methane oxidation within the redox-zone based on physical parameters and on board gas chemistry, and (2) recovering samples from the relevant depth interval for home-based molecular biological and lipid biomarker studies to identify the microorganisms involved in methane oxidation. These samples were taken within a time frame of 3 days and with different sampling equipment (as described below).

\subsection{Physical parameters and gas chemistry}

Water stations for analyses of the gas chemistry were carried out with a rosette water sampler equipped with twenty-four 10 L Hydro-bios Free Flow bottles. For continuous CTD and turbidity profiling a Seabird sbe911+ system, together with a turbidity sensor (ECO FLNTU, WET Labs) were attached to the underwater unit.

The oxygen distribution was measured according to Winkler's method, whereas hydrogen sulfide was analysed colorimetrically with the methylene blue method (Grasshoff et al., 1983).

Water samples $(600 \mathrm{~mL})$ for methane analyses were transferred directly from the sample bottle into pre-evacuated 
$1100 \mathrm{~mL}$ glass bottles. Dissolved methane was extracted using a vacuum degassing method and its mole fraction was determined with a gas chromatograph equipped with a flame ionisation detector (Trace GC, Thermo Electron). The average precision of this method is $\pm 3 \%$ (Keir et al., 2009).

For the determination of $\delta^{13} \mathrm{CCH}_{4}$ values, subsamples of the extracted gas were analysed at the Leibniz Institute for Baltic Sea Research Warnemünde using an isotope-ratio mass spectrometer (modified after Schmale et al., 2010a). These subsamples were collected in $10 \mathrm{~mL}$ pre-evacuated crimp-top glass vials containing $4 \mathrm{~mL}$ of supersaturated salt solution (degassed Millipore water, poisoned with $\mathrm{HgCl}_{2}$ ) and sealed with a butyl rubber septum. Stable carbon isotope analysis involved removal of water and carbon dioxide on a $\mathrm{NaOH} /$ Ascarite trap, double cryofocusing at $-110^{\circ} \mathrm{C}$ (ethanol/nitrogen) on Hayesep D and Poraplot S columns, gas-release by heating the traps separately to $40^{\circ} \mathrm{C}$ and gas separation on a MolSieve 5A Plot capillary column (Supelco, $30 \mathrm{~m}$, I.D. $0.32 \mathrm{~mm}$ ) at $30^{\circ} \mathrm{C}$ (Trace GC Ultra, Thermo Electron), combustion to $\mathrm{CO}_{2}$ using a Ni catalyst at $1050^{\circ} \mathrm{C}$, removal of combustion water using a Nafion trap, and injection into a MAT 253 mass spectrometer (Thermo Electron, Bremen) using a continuous flow technique. The $\delta^{13} \mathrm{C} \mathrm{CH}_{4}$ data is expressed vs. Vienna Pee Dee Belemnite (VPDB) standard. Calibration of the system was performed daily by the use of a $\mathrm{CH}_{4}$ standard with known isotopic composition. The average precision of that method is $\pm 1 \%$.

\section{2 pmoA gene expression analyses}

Within the identified redox-zone filter samples were taken in $80,100,105$ and $119 \mathrm{~m}$ water depth using a rosette water sampler. $1000 \mathrm{~mL}$ of sample water were filtered on a Durapore filter $(0.2 \mu \mathrm{m}$ pore size $)$, frozen in liquid nitrogen and stored at $-80^{\circ} \mathrm{C}$.

For each sample RNA was extracted from the frozen filter with acidic phenol (Weinbauer et al., 2002) and quantified using a NanoDrop ND-1000 spectrometer (NanoDrop Technologies). To generate $p m o A$-specific cDNA, $100 \mathrm{ng}$ RNA was reverse transcribed using the iScript Select cDNA Synthesis Kit (Biorad) and reverse primer mb661r (Costello and Lidstrom, 1999). To detect potential DNA contamination one sample was incubated without reverse transcriptase. $1 \mu \mathrm{L}$ of cDNA was amplified by Polymerase Chain Reaction (PCR). For the generation of specific GC-clamped PCR products a discontinuous PCR was applied: reactions $(50 \mu \mathrm{L})$ containing $1 \times$ PCR buffer, $200 \mu \mathrm{M}$ of each dNTP, $0.3 \mu \mathrm{M}$ revere primer mb661r, $0.1 \mu \mathrm{M}$ forward primer A189f (Holmes et al., 1995), $0.5 \mathrm{mM} \mathrm{MgCl}_{2}, 0.5 \mu \mathrm{L}$ polymerase (Herculase II, Fusion) and template cDNA were incubated at initial $94^{\circ} \mathrm{C}$ for $5 \mathrm{~min}$. After 20 cycles of $60 \mathrm{~s}$ at $94^{\circ} \mathrm{C}, 60 \mathrm{~s}$ at $56^{\circ} \mathrm{C}$ and $30 \mathrm{~s}$ at $72{ }^{\circ} \mathrm{C}$, the PCR was paused at $72{ }^{\circ} \mathrm{C}$ and $0.12 \mu \mathrm{M}$ A189f_GC primer were added to each reaction. Afterwards the PCR was resumed for another 15 cycles with conditions as described above, followed by a final elongation step of $5 \mathrm{~min}$ at $72^{\circ} \mathrm{C}$.
Specificity of the PCR products was documented by agarose gel electrophoresis and staining with ethidium bromide. The described discontinuous PCR yielded more specific and distinct PCR products than a conventional PCR with GC-primer (data not shown).

PCR products were separated by Denaturing Gradient Gel Electrophoresis (DGGE) using a gradient of $35 \%$ to $80 \%$ denaturant in a $6 \%$ polyacrylamide gel. Electrophoresis ran at $100 \mathrm{~V}$ and $60^{\circ} \mathrm{C}$ for $16 \mathrm{~h}$ in $1 \times$ TAE buffer. The gel was stained with a $1: 5000$ dilution of SYBRGold (Invitrogen) for $30 \mathrm{~min}$. All bands from each depth were excised and reamplified in a PCR reaction containing $1 \times$ PCR buffer, $0.3 \mu \mathrm{M}$ of A189f and mb661r each, $200 \mu \mathrm{M}$ of each dNTP and $0.5 \mu \mathrm{L}$ polymerase in 30 cycles with an annealing temperature of $56^{\circ} \mathrm{C}$. PCR products were purified with NucleoSpin purification kit (Macherey-Nagel) and sequenced with primers A189f and mb661r by AGOWA (Berlin, Germany).

Forward and reverse sequences were checked for quality applying Seqman software (DNASTAR).

For phylogenetic analysis the ARB software package was used (Ludwig et al., 2004). Alignment was based on partial DNA sequences of $p m o A$ and $a m o A$ genes obtained from GenBank Database with partial sequences of amoA (Accession numbers: AF037107, AF043710, AF037108) serving as an outgroup in the tree construction. Sequences for analysis were reduced to unambiguously alignable positions.

Three different trees were calculated using the algorithms maximum likelihood (PHYML), maximum parsimony and neighbour-joining with Jukes-Cantor correction.

Nucleotide sequence accession numbers are deposited in the GenBank database (accession number KC188735).

\subsection{Lipid biomarkers}

For lipid biomarker studies a sample was selected from the centre of the redox-zone at $100 \mathrm{~m}$ water depth. That depth was chosen to obtain a POM sample that reflects the in situ microbial turnover of methane under low-oxygen conditions and is not "contaminated" by external water masses (i.e. increased oxygen concentrations or anoxic conditions) which may also include other methane consuming microorganisms (e.g. consortia performing the anaerobic oxidation of methane). $214 \mathrm{~L}$ of water were filtered on glass microfiber filters $(\varnothing 30 \mathrm{~cm} ; 0.7 \mu \mathrm{m}$ pore size) over a time span of two hours using a PUMP-CTD system (Strady et al., 2008). Half of the filter was extracted in triplicate with dichloromethane and methanol $(3: 1, v: v)$ in a CEM Mars 5 microwave (Matthews, NC) at $80^{\circ} \mathrm{C}$ and $800 \mathrm{~W}$. An aliquot of the sample was acetylated with acetic acid/pyridine as described elsewhere (Blumenberg et al., 2007) and analysed using high performance liquid chromatography-mass spectrometry (LC-MS). LC-MS was performed using a Varian Prostar Dynamax HPLC system coupled to a Varian $1200 \mathrm{~L}$ triple quadrupole mass spectrometer (for analytical details see Blumenberg et al., 2010). Another aliquot of the extract was 


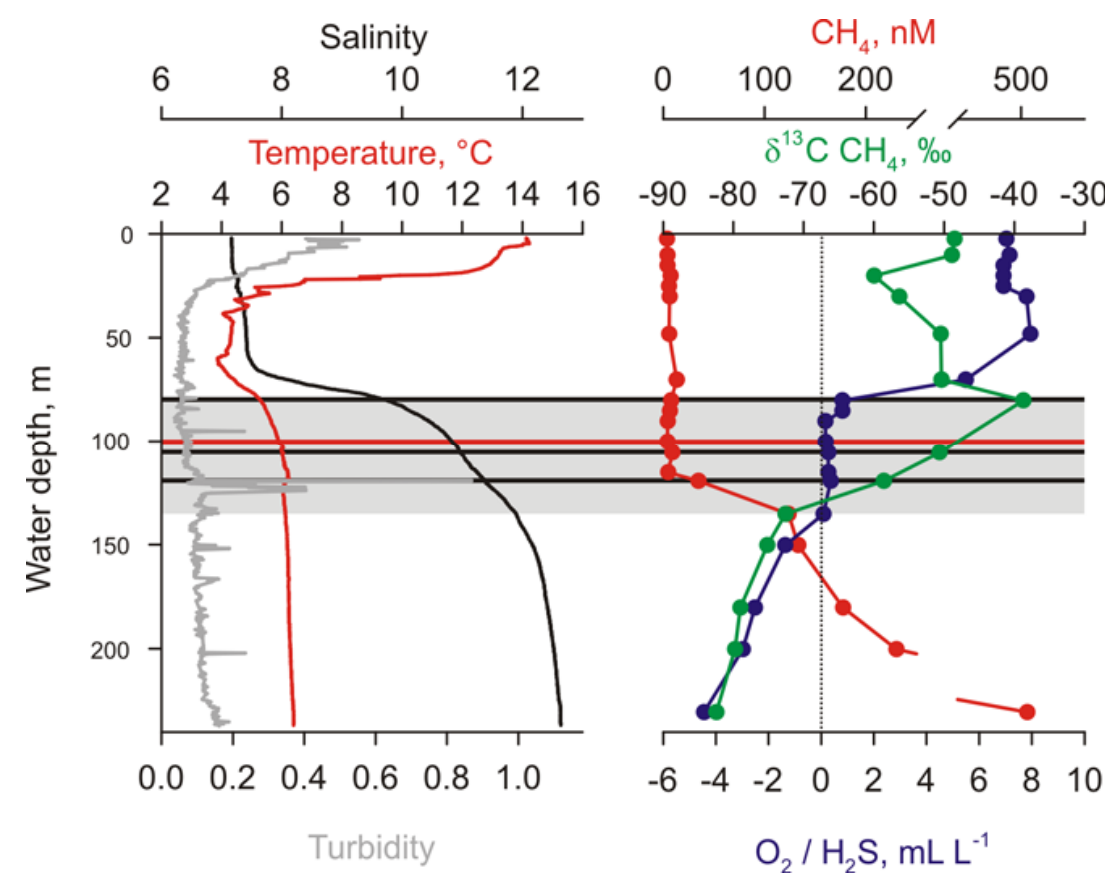

Fig. 2. Left: vertical distribution of salinity (black), temperature (red), and turbidity (grey). Right: vertical distribution of oxygen and hydrogen sulfide (expressed as negative oxygen equivalents, blue), methane (red), and $\delta^{13} \mathrm{C}$ value of methane (green). The depth interval of the redox-zone is displayed in grey (oxygen concentration $0-0.8 \mathrm{~mL} \mathrm{~L}^{-1}$ ). The water depths for molecular biological and lipid biomarker studies are indicated with coloured horizontal lines (black = molecular biology, red = molecular biology together with lipid biomarkers).

separated by column chromatography into a hydrocarbon $(\mathrm{F} 1)$, an alcohol and ketone (F2), and a polar fraction (F3) using a column $(\varnothing \sim 1 \mathrm{~cm})$ filled with $7.5 \mathrm{~g}$ silica gel 60 (according to Blumenberg et al., 2010). (F3) was transmethylated using trimethylchlorosilane in methanol $(1: 8 ; v: v$; $1.5 \mathrm{~h}$ at $\left.80^{\circ} \mathrm{C}\right)$. Double bond positions within unsaturated fatty acid methyl esters were determined by derivatisation with dimethyldisulfide (DMDS; method modified after Carlson et al., 1989 and Gatellier et al., 1993). The polar fraction (F3), and the DMDS derivatized sample were analysed with coupled gas chromatography-mass spectrometry (GC-MS) using a Varian CP-3800 gas chromatograph equipped with a fused silica column (Phenomenex Zebron ZB-5MS, $30 \mathrm{~m}$, I.D. $0.32 \mathrm{~mm}$ ) coupled to a Varian 1200L mass spectrometer. He was used as carrier gas. The temperature program was $80^{\circ} \mathrm{C}(3 \mathrm{~min})$ to $310^{\circ} \mathrm{C}$ (held $25 \mathrm{~min}$ ) at $4^{\circ} \mathrm{C} \mathrm{min}{ }^{-1}$. Compounds were identified by comparing mass spectra and retention times to published data. $\delta^{13} \mathrm{C}$ values of fatty acid methyl esters from the polar fraction (F3) were measured in replicate as described previously (Blumenberg et al., 2010). The precision was generally better than $0.5 \%$.

\section{Results and discussion}

\subsection{Physical parameters and gas chemistry}

The estuarine circulation in the Baltic Sea causes a strong vertical salinity gradient between the surface and deep water (Lass and Matthäus, 2008). This gradient is very pronounced in the deep basins of the central Baltic Sea (e.g. Gotland and Landsort Deep; Fig. 2) and reflects a water column stratification that limits the vertical mixing and water renewal in the deep strata (Reissmann et al., 2009). Oceanographic investigations, carried out at the redox-zone of the Gotland Deep, show that this depth is periodically perturbed by intrusions, internal waves or eddies which can shift the amplitudes of isoclines up to $10 \mathrm{~m}$ within time spans less than an hour (shown for temperature and salinity in Lass et al., 2003; Dellwig et al., 2012).

During sampling, the specific water column structure led to oxygen deficiency below a water depth of about $80 \mathrm{~m}$. Further downward, the oxygen concentrations decreased below $0.8 \mathrm{~mL} \mathrm{~L}^{-1}$, characterizing the redox-zone between the oxic surface and anoxic deep waters. The lower boundary of the redox-zone was located at about $138 \mathrm{~m}$ water depth where the concentration of hydrogen sulphide $\left(\mathrm{H}_{2} \mathrm{~S}\right)$ started to increase. A distinct turbidity anomaly was observed at about $120 \mathrm{~m}$ water depth (Fig. 2). This specific feature is known from other anoxic basins like the Black Sea and is 


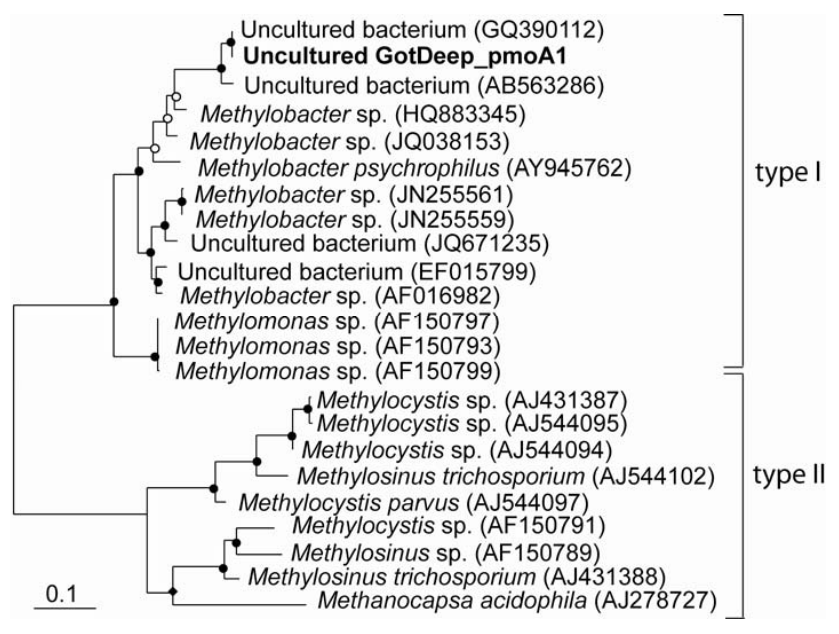

Fig. 3. Unrooted maximum likelihood tree showing the phylogenetic affiliation of the partial pmoA DNA sequence generated from the filter samples taken in $80,100,105$ and $119 \mathrm{~m}$ water depth (marked bold). Black circles $=$ validation of subtree by neighbourjoining and parsimony; white circles $=$ validation of subtree by parsimony; black diamond = validation of subtree by neighbourjoining. Scale bar represents 10 substitutions per 100 nucleotides. For tree construction partial amoA sequences were used as an outgroup (not shown).

most likely caused by the precipitation of iron and manganese oxides (Kempe et al., 1991) and an enrichment of particulate organic matter (POM) due to enhanced microbial activity (Prokhorenko et al., 1994). The concentrations of $\mathrm{H}_{2} \mathrm{~S}$ and other reduced chemical species like ammonium $\left(\mathrm{NH}_{4}^{+}\right)$are constantly increasing with depth, indicating an upward flux from the sediment or deep water towards the redox-zone (Nausch et al., 2008). The same concentration pattern was observed for methane (Fig. 2). Highest methane concentrations were detected close to the seafloor $(504 \mathrm{nM}$ at $230 \mathrm{~m}$ water depth) supporting an origin from methanogenesis in the sediment (Piker et al., 1998). Indeed, low $\delta^{13} \mathrm{C} \mathrm{CH}_{4}$ values ( $-82.4 \%$ o to $-75.2 \%$, Fig. 2$)$ observed in the anoxic water body clearly point at a microbial methane source (Whiticar, 1999). The methane concentration profile shows a pronounced decrease within the redox-zone from $124 \mathrm{nM}$ at $135 \mathrm{~m}$ water depth to $4.8 \mathrm{nM}$ at $115 \mathrm{~m}$ water depth. At the same time, $\delta^{13} \mathrm{C} \mathrm{CH}_{4}$ values substantially increase (up to $-38.7 \%$ at $80 \mathrm{~m}$ water depth). As microbial reactions favour the incorporation of ${ }^{12} \mathrm{C}$ and thus, enrichment in ${ }^{13} \mathrm{CH}_{4}$ in the residual methane pool, this isotopic shift clearly indicates microbial methane oxidation within that water level (Whiticar, 1999). In a first approximation the methane oxidation rate can be derived from the methane gradient and the vertical transport velocity. Using the vertical diffusivity $\left(k_{z}\right)$ of $0.95 \mathrm{~m}^{2} \mathrm{~d}^{-1}$ (Axell, 1998) in combination with the methane distribution between $115 \mathrm{~m}(4.8 \mathrm{nM})$ and at $135 \mathrm{~m}$ water depth $(124 \mathrm{nM})$ this calculation leads to a flux of methane of $5.7 \mu \mathrm{mol} \mathrm{m}^{-2} \mathrm{~d}^{-1}$. If we assume that this
Table 1. Concentrations, relative abundances and $\delta^{13} \mathrm{C}$ values of individual fatty acids (analysed as methyl ester derivatives) at $100 \mathrm{~m}$ water depth of the Gotland Deep. Fatty acids specific for methanotrophic bacteria are given in bold letters.

\begin{tabular}{|c|c|c|c|}
\hline Fatty acid & $\begin{array}{l}\text { Concentration } \\
{\left[\mu \mathrm{g} \mathrm{g}^{-1} \mathrm{C}_{\mathrm{org}}\right]}\end{array}$ & $\begin{array}{l}\% \text { of total } \\
\text { fatty acids }\end{array}$ & $\delta^{13} \mathrm{C}[\% \circ]$ \\
\hline C14 : 0 & 37.8 & 0.7 & -26.9 \\
\hline iC15 : 0 & 86.1 & 1.6 & -21.5 \\
\hline aiC $15: 0$ & 101.4 & 1.9 & -26.2 \\
\hline C15 : 0 & 86.0 & 1.6 & -25.8 \\
\hline iC16: 0 & 29.4 & 0.5 & -29.7 \\
\hline $\mathrm{C} 16: 1 \omega 9 \mathrm{t}$ & 31.4 & 0.6 & -22.2 \\
\hline $\mathrm{C} 16: 1 \omega 8 \mathrm{c}$ & 9.8 & 0.2 & -38.8 \\
\hline $\mathrm{C} 16: 1 \omega 8 \mathrm{t}$ & 33.0 & 0.6 & -30.4 \\
\hline $\mathrm{C} 16: 1 \omega 7 \mathrm{c}$ & 231.0 & 4.2 & -27.6 \\
\hline $\mathrm{C} 16: 1 \omega 7 \mathrm{t}$ & 57.0 & 1.0 & - \\
\hline $\mathrm{C} 16: 1 \omega 5 \mathrm{c}$ & 66.1 & 1.2 & -35.7 \\
\hline $\mathrm{C} 16: 1 \omega 5 \mathrm{t}$ & 22.2 & 0.4 & -33.8 \\
\hline C16: 0 & 1300.1 & 23.7 & -26.9 \\
\hline iC17 : 0 & 9.7 & 0.2 & -29.6 \\
\hline aiC17 : 0 & 16.3 & 0.3 & -28.6 \\
\hline C17 : 0 & 63.2 & 1.2 & -30.9 \\
\hline $\mathrm{C} 18: 2$ & 41.4 & 0.8 & -25.4 \\
\hline $\mathrm{C} 18: 3$ & 32.5 & 0.6 & - \\
\hline $\mathrm{C} 18: 1 \omega 9 \mathrm{c}$ & 246.4 & 4.5 & -26.5 \\
\hline $\mathrm{C} 18: 1 \omega 7 \mathrm{c}$ & 232.6 & 4.2 & -24.9 \\
\hline $\mathrm{C} 18: 1 \omega 6 \mathrm{c}$ & 15.0 & 0.3 & -30.9 \\
\hline $\mathrm{C} 18: 1 \omega 5 \mathrm{c}$ & 9.0 & 0.2 & -20.2 \\
\hline $\mathrm{C} 18: 0$ & 2279.4 & 41.6 & -27.1 \\
\hline iC19: 0 & 49.7 & 0.9 & -26.5 \\
\hline C19: 0 & 47.5 & 0.7 & - \\
\hline $\mathrm{C} 20: 0$ & 154.0 & 2.8 & -29.6 \\
\hline $\mathrm{C} 21: 0$ & 20.1 & 0.4 & - \\
\hline $\mathrm{C} 22: 0$ & 102.7 & 1.9 & -29.7 \\
\hline $\mathrm{C} 24: 0$ & 77.2 & 1.4 & - \\
\hline
\end{tabular}

flux is oxidized within the $20 \mathrm{~m}$ depth interval, we receive a methane consumption rate of $0.28 \mathrm{nMd}^{-1}$. An inverse trend in methane carbon isotope ratios is observed above the suboxic layer (Fig. $2 ; \delta^{13} \mathrm{C}$ ratios between $-59.9 \%$ o and $-48.5 \%$ o). This trend is probably caused by (1) the downward ventilation of atmospheric methane $(-47.4 \%$; http://www.esrl.noaa.gov/gmd/ccgg/iadv/), and/or (2) microbial methane production in shallow waters. The process of methane formation in an oxygenated water column has been observed in many regions (Holmes et al., 2000; Schmale et al., 2010a) and seems to be related to the decay of methylphosphonates, in particular under phosphate-limiting conditions, and/or methanogenesis in the anoxic interior of particles (Karl et al., 2008). Such methane forming processes are also indicated in our dataset by a pronounced ${ }^{13} \mathrm{CH}_{4}$ depletion at $20 \mathrm{~m}$ water depth $\left(\delta^{13} \mathrm{C}=-59.9 \%\right.$ ) together with slightly elevated methane concentrations of $7 \mathrm{nM}$ (surrounding water depths around $4 \mathrm{nM}$ ). However, within the surface water, methane is only slightly enriched compared with the 


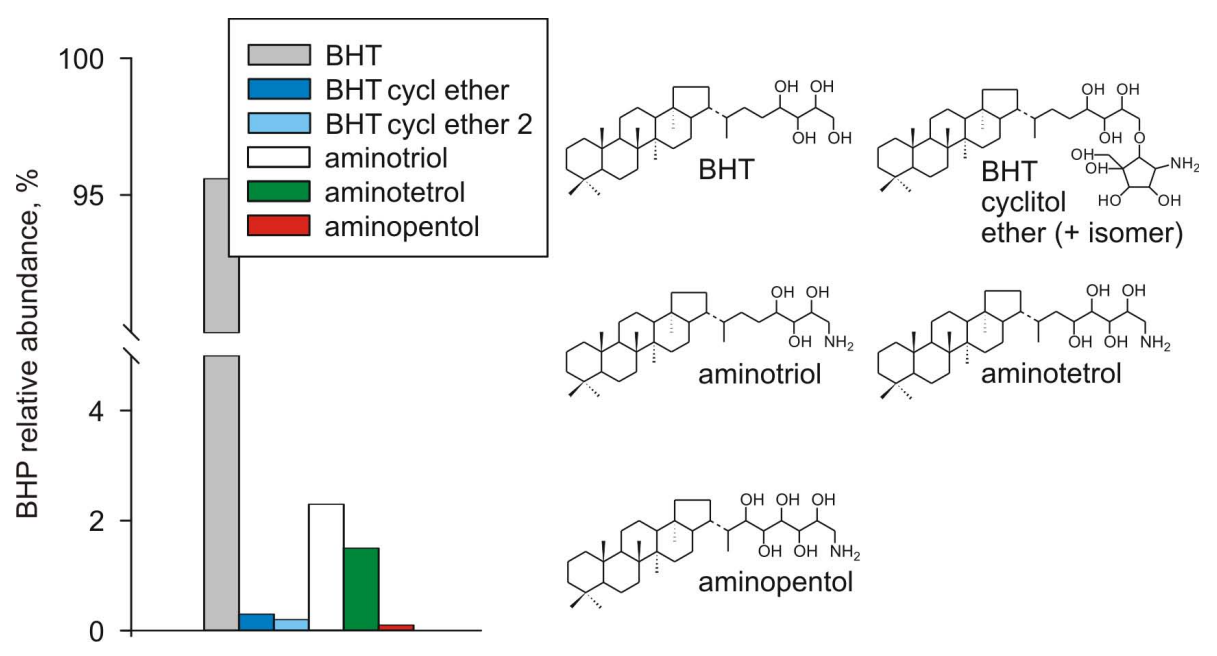

Fig. 4. The relative abundances of specific bacteriohopanepolyols (BHPs) sampled in $100 \mathrm{~m}$ water depth, together with the chemical structure of each compound. BHT = bacteriohopanetetrol; cycl = cyclitol.

atmospheric equilibrium (144\% saturation ratio; Schmale et al., 2010b), indicating that the local emission of methane into the atmosphere is rather low.

\subsection{Methanotrophic microorganisms within the redox-zone}

Chemical gradients feature versatile environments and are known to harbour enhanced microbial abundance and activity. Within the redox-zone of the central Baltic Sea, various biogeochemical processes have been identified, such as denitrification, ammonia oxidation, or dark $\mathrm{CO}_{2}$ fixation (Labrenz et al., 2005; Jost et al., 2008; Glaubitz et al., 2009; Labrenz et al., 2010) and also microbial consumption of methane was proposed as mechanism explaining the strong methane decrease in this water layer (Schmale et al., 2010a).

To gain information on the contribution of methanotrophic microorganisms to the POM within the redox-zone, we performed expression analyses of the methane monooxygenase gene ( bacteriohopanepolyols (BHPs).

The presence of methanotrophic bacteria was proved by molecular biological studies carried out on samples obtained from 80, 100, 105 and $119 \mathrm{~m}$ water depth (Fig. 2). Although the two groups of methanotrophs, type I and type II, use different physiological pathways for the assimilation of carbon from methane, namely the ribulose monophosphate pathway and the serine pathway, the key enzyme methane monooxygenase responsible for the initial oxidation of methane to methanol is present in both groups. The gene coding for the alpha subunit of the particulate form of the enzyme ( $p m o A$ ) has been used as a marker for the detection and characterisation of methanotrophic communities in different habitats (Costello and Lidstrom, 1999; Bourne et al., 2001; Chen et al., 2007; Chen et al., 2008). In order to identify active methanotrophs we investigated $p m o A$ gene expression in situ. Based on DGGE analysis only one type of $p m o A$ transcript, named Uncultured GotDeep_pmoA1, was present throughout the redox-zone. Phylogenetically it is affiliated with the type I methanotrophs and practically identical to an uncultured bacterium found in the meromictic crater lake Lac Pavin (Fig. 3). With a permanently anoxic monimolimnion, also due to a halocline, elevated concentrations of $\mathrm{CH}_{4}$ and nearly identical temperatures around $5-6^{\circ} \mathrm{C}$ (Aeschbach-Hertig et al., 2002) environmental conditions in Lac Pavin are in some aspects comparable to the central Baltic Sea (Fig. 2). Thus, activity of these identified methanotrophs could be indicative of this kind of habitat.

To support these findings, an additional POM sample obtained in the centre of the redox-zone was investigated for lipid biomarkers. Of special biomarker value are BHPs with an A-ring methylation at C-3 (Neunlist and Rohmer, 1985) and/or an amino group at C-35 of the hopanoid structure, both of which are widespread in methanotrophic bacteria (Neunlist and Rohmer, 1985; Talbot et al., 2001). The vast majority of BHPs was composed of bacteriohopane-32,33,34,35-tetrol (BHT) and 35-aminobacteriohopane-32,33,34-triol (aminotriol), the most common and thus unspecific BHPs (Fig. 4). C-3 methylated BHPs were not observed. However, low abundances of 35-aminobacteriohopane-31,32,33,34-tetrol (aminotetrol) and of 35-aminobacteriohopane-30,31,32,33,34-pentol (aminopentol) were found (Fig. 4). Whereas both these amino-BHPs are considered indicative of methanotrophic bacteria (Neunlist and Rohmer, 1985; Talbot and Farrimond, 2007), particularly the latter is even regarded as a biomarker for the type I subgroup (gamma proteobacteria; Talbot and Farrimond, 2007). Further evidence for a prominent contribution of type I methanotrophs comes from the fatty acids $\mathrm{C} 16: 1 \omega 8 \mathrm{c}$ and $\mathrm{C} 16: 1 \omega 5 \mathrm{c}$ which are considered as specific 
to this group (Makula, 1978; Nichols et al., 1985; Table 1). At the same time the lack of $\mathrm{C} 18: 1 \omega 8 \mathrm{c}$, a fatty acid specific of type II methanotrophs (alpha proteobacteria, Bowmann et al., 1991), indicates that these microorganisms do not play a significant role for the methane turnover at the redox-zone of the Gotland Deep. Biomarkers from methanotrophic bacteria commonly show the isotopic traits of the substrate (Summons et al., 1994). Indeed the $\delta^{13} \mathrm{C}$ values of the fatty acids $\mathrm{C} 16: 1 \omega 8 \mathrm{c}$ and $\mathrm{C} 16: 1 \omega 5 \mathrm{c}(-38.8 \%$ and $-35.5 \%$, respectively; Table 1) are well within the $\delta^{13} \mathrm{C} \mathrm{CH}_{4}$ at 80 and $105 \mathrm{~m}(=-38.7 \%$ and $-50.6 \%$, respectively; Fig. 2). Whereas biomarker indications for the presence of methanotrophic bacteria exist, their relative abundance among the bacterial community appears to be low. This is indicated (i) by the low proportion of methanotroph-specific amino-BHPs within the total BHPs $(<1.6 \%$ of total BHPs; note that amino-BHPs are often predominant in methanotrophs; Talbot et al., 2001), and (ii) by the low amounts of type I specific fatty acids acids (C16: $1 \omega 8 \mathrm{c}$ and $\mathrm{C} 16: 1 \omega 5 \mathrm{c}$ represent $1.4 \%$ of total fatty acids).

Thus, in contrast to studies in the redox-zone of the Black Sea, where indications for type I, II and X were found (Gal'chenko et al., 1988; Durisch-Kaiser et al., 2005; Blumenberg et al., 2007), the diversity of active aerobic methanotrophs in the redox-zone of the Gotland Deep seemed to be restricted. These findings are only based on one dataset, but it would be in line with previous studies investigating the microbial catalysts of denitrification, nitrification, or dark $\mathrm{CO}_{2}$ fixation in central Baltic Sea redox-zones which also revealed that these pathways were actively driven by only a few bacterial or archaeal key species (Grote et al., 2008; Glaubitz et al., 2009; Labrenz et al., 2010). An explanation for the reduced diversity of active microorganisms along the central Baltic Sea redox-zone could be the periodic perturbation of the stratification which does not occur in the same strength and frequency in the Black Sea. An overlap of sulfide- and oxygen-containing waters can occur in the Gotland Basin (Axell, 1998), and it is known that sulfide is toxic for many organisms or at least can inhibit the activity of specific microorganisms (Erguder et al., 2009). Thus, potential sulfide stress could inhibit other than type I methanotrophic bacteria within the redox-zone of the Gotland Deep, but this interesting aspect needs further investigation.

\section{Conclusion}

Using a multidisciplinary approach of gas chemistry, molecular biology, and lipid geochemistry, we identified the process of aerobic methane oxidation within the pelagic redox-zone of the Gotland Deep (central Baltic Sea). This was evidenced by a strong decrease in methane concentrations together with a ${ }^{13} \mathrm{CCH}_{4}$ enrichment, the detection of the key enzyme methane monooxygenase (pmoA), and the occurrence of lipids specific for methanotrophic bacte- ria (e.g., aminopentol; $16: 1 \omega 8 \mathrm{c}$ fatty acid). Phylogenetic and biomarker data indicate that the diversity of active aerobic methanotrophs in the redox-zone of the Gotland Deep was restricted to members of the type I subgroup. In contrast to other marine settings with a permanent stratification, e.g. the Black Sea, the physical and biogeochemical structure of the Gotland Deep is periodically disturbed by intrusions, eddies, internal waves or long-term vertical transport mechanisms. How this variable environment is affecting the methane turnover in the water column and the microbial community responsible for this process is an interesting question that needs to be investigated in future studies. Also the transferability of our results on a basin scale needs to be addressed as some parts of the basin (e.g. the basin boundaries) are permanently influenced by intrusions and elevated vertical mixing that might influence the processes involved in the turnover of methane.

Acknowledgements. We thank the captain, officers and crew aboard R/V Maria S. Merian (MSM 08/3) for their assistance on sea. We gratefully acknowledge the efforts of G. Nausch and $\mathrm{S}$. Krüger in carrying out the oxygen and hydrogen sulfide analysis as well as the CTD work on the cruise. We also thank J. Dyckmans (Centre for Stable Isotope Research and Analysis, University of Göttingen) for help with compound specific carbon isotope analysis and T. Licha and K. Nödler for support with LC-MS analyses. We thank Marcus Elvert and an unknown reviewer for their thoughtful reviews and comments. The study was supported by the Deutsche Forschungsgemeinschaft (DFG) through grants SCHM 2530/2-1, BL 971/3-1, and BL 971/1-3.

Edited by: G. Herndl

\section{References}

Aeschbach-Hertig, W., Hofer, M., Schmid, M., Kipfer, R., and Imboden, D. M: The physical structure and dynamics of a deep, meromictic crater lake (Lac Pavin, France), Hydrobiologia, 487, 111-136, 2002.

Axell, L. B.: On the variability of Baltic Sea deepwater mixing, J. Geophys. Res.-Oceans, 103, 21667-21682, 1998.

Bange, H. W., Bartell, U. H., Rapsomanikis, S., and Andreae, M. O.: Methane in the Baltic and Noth Seas and a reassessment of the marine emission of methane, Global Biogeochem. Cy., 8, 465480, 1994.

Barnes, R. O. and Goldberg, E. D.: Methane production and consumption in anaerobic marine sediments, Geology, 4, 297-300, 1976.

Beal, E. J., House, C. H., and Orphan, V. J.: Manganese- and IronDependent Marine Methane Oxidation, Science, 325, 184-187, doi:10.1126/science.1169984, 2009.

Blumenberg, M., Seifert, R., and Michaelis, W.: Aerobic methanotrophy in the oxic-anoxic transition zone of the Black Sea water column, Org. Geochem., 2007.

Blumenberg, M., Mollenhauer, G., Zabel, M., Reimer, A., and Thiel, V.: Decoupling of bio- and geohopanoids in sediments 
of the Benguela Upwelling System (BUS), Org. Geochem., 41, 1119-1129, 2010.

Bourne, D. G., McDonald, I. R., and Murrell, J. C.: Comparison of pmoA PCR Primer Sets as Tools for Investigating Methanotroph Diversity in Three Danish Soils, Appl. Environ. Microbiol., 67, 3802-3809, 2001.

Bowmann, J. P., Skerratt, J. H., Nichols, P. D., and Sly, L. I.: Phospholipid fatty acid and lipopolysaccharide fatty acid signature lipids in methane-utilizing bacteria, FEMS Microbiol. Ecol., 85, 15-22, 1991.

Carlson, D. A., Roan, C. S., Yost, R. A., and Hector, J.: Dimethyl disulfide derivatives of long chain alkenes, alkadienes, and alkatrienes for gas chromatography/mass spectrometry, Anal. Chem., 61, 1564-1571, doi:10.1021/ac00189a019, 1989.

Chen, Y., Dumont, M. G., Cébron, A., and Murrell, J. C.: Identification of active methanotrophs in a landfill cover soil through detection of expression of $16 \mathrm{~S}$ rRNA and functional genes, Environ. Microbiol., 9, 2855-2869, doi:10.1111/j.14622920.2007.01401.x, 2007.

Chen, Y., Dumont, M. G., McNamara, N. P., Chamberlain, P. M., Bodrossy, L., Stralis-Pavese, N., and Murrell, J. C.: Diversity of the active methanotrophic community in acidic peatlands as assessed by mRNA and SIP-PLFA analyses, Environ. Microbiol., 10, 446-459, doi:10.1111/j.1462-2920.2007.01466.x, 2008.

Costello, A. M. and Lidstrom, M. E.: Molecular characterization of fuctional and phylogenetic genes from natural populations pf methanotrophs in lake sediments, Appl. Environ. Microbiol., 65, 5066-5074, 1999.

Dando, P. R., O’Hara, S. C. M., Schuster, U., Taylor, L. J., Clayton, C. J., Baylis, S., and Laier, T.: Gas seepage from a carbonatecemented sandstone reef on the Kattegat coast of Denmark, Mar. Petrol. Geol., 11, 182-189, 1994.

Dellwig, O., Schnetger, B., Brumsack, H.-J., Grossart, H.-P., and Umlauf, L.: Dissolved reactive manganese at pelagic redoxclines (part II): Hydrodynamic conditions for accumulation, J. Marine Syst., 90, 31-41, 2012.

Durisch-Kaiser, E., Klauser, L., Wehrli, B., and Schubert, C.: Evidence of intense archaeal and bacterial methanotrophic activity in the Black Sea water column, Appl. Environ. Microbiol., 71, 8099-8106, 2005.

Erguder, T. H., Boon, N., Wittebolle, L., Marzorati, M., and Verstraete, W.: Environmental factors shaping the ecological niches of ammonia-oxidizing archaea, FEMS Microbiol. Rev., 33, 855869, doi:10.1111/j.1574-6976.2009.00179.x, 2009.

Ettwig, K. F., Butler, M. K., Le Paslier, D., Pelletier, E., Mangenot, S., Kuypers, M. M. M., Schreiber, F., Dutilh, B. E., Zedelius, J., de Beer, D., Gloerich, J., Wessels, H. J. C. T., van Alen, T., Luesken, F., Wu, M. L., van de Pas-Schoonen, K. T., Op den Camp, H. J. M., Janssen-Megens, E. M., Francoijs, K.-J., Stunnenberg, H., Weissenbach, J., Jetten, M. S. M., and Strous, M.: Nitrite-driven anaerobic methane oxidation by oxygenic bacteria, Nature, 464, 543-548, 2010.

Gal'chenko, V. F., Abranochkina, F. N., Bezukova, L. V., Sokolova, E. N., and Ivanov, M. V.: Species composition of the aerobic methanotrophic microflora of the Black Sea, Microbiology, 57, 305-311, 1988.

Gatellier, J.-P. L. A., de Leeuw, J. W., Sinninghe Damsté, J. S., Derenne, S., Largeau, C., and Metzger, P.: A comparative study of macromolecular substances of a Coorongite and cell walls of the extant alga Botryococcus braunii, Geochim. Cosmochim. Ac., 57, 2053-2068, 1993.

Glaubitz, S., Lueders, T., Abraham, W.-R., Jost, G., Jürgens, K., and Labrenz, M.: ${ }^{13} \mathrm{C}$-isotope analyses reveal that chemolithoautotrophic Gamma- and Epsilonproteobacteria feed a microbial food web in a pelagic redoxcline of the central Baltic Sea, Environ. Microbiol., 11, 326-337, 2009.

Grasshoff, K., Erhardt, M., and Kremling, K.: Methods of seawater analysis, Verlag Chemie, Weinheim, Germany, 1983.

Grote, J., Jost, G., Labrenz, M., Herndl, G. J., and Jürgens, K.: Epsilonproteobacteria Represent the Major Portion of Chemoautotrophic Bacteria in Sulfidic Waters of Pelagic Redoxclines of the Baltic and Black Seas, Appl. Environ. Microb., 74, 75467551, 2008.

Hinrichs, K. U. and Boetius, A.: The Anaerobic Oxidation of Methane: New Insights in Microbial Ecology and Biogeochemistry, in: Ocean Margin Systems, edited by: Wefer, G., Billett, D., Hebbeln, D., Jörgensen, B. B., Schlüter, M., and Van Weering, T., Springer Verlag, Berlin Heidelberg, 457-477, 2002.

Holmes, A. J., Costello, A., Lidstrom, M. E., and Murrell, J. C.: Evidence that participate methane monooxygenase and ammonia monooxygenase may be evolutionarily related, FEMS Microbiol. Lett., 132, 203-208, doi:10.1111/j.1574-6968.1995.tb07834.x, 1995.

Holmes, M. E., Sansone, F. J., Rust, T. M., and Popp, B. N.: Methane production, consumption, and air-sea exchange in the open ocean: An Evaluation based on carbon isotopic ratios, Global Biogeochem. Cy., 14, 1-10, doi:10.1029/1999gb001209, 2000.

Holtermann, P. L. and Umlauf, L.: The Baltic Sea Tracer Release Experiment: 2. Mixing processes, J. Geophys. Res., 117, C01022, doi:10.1029/2011jc007445, 2012.

Jost, G., Zubkov, M. V., Yakushev, E. V., Labrenz, M., and Jürgens, K.: High abundance and dark $\mathrm{CO}_{2}$ fixation of chemolithoautotrophic prokaryotes in anoxic waters of the Baltic Sea, Limnol. Oceanogr., 53, 14-22, 2008.

Karl, D. M., Beversdorf, L., Bjorkman, K. M., Church, M. J., Martinez, A., and Delong, E. F.: Aerobic production of methane in the sea, Nat. Geosci., 1, 473-478, 2008.

Keir, R., Schmale, O., Seifert, R., and Sültenfuß, J.: Isotope fractionation and mixing in methane plumes from the Logatchev hydrothermal field, Geochem. Geophy. Geosy., 10, Q05005, doi:10.1029/2009GC002403, 2009.

Kempe, S., Diercks, A.-R., Liebezeit, G., and Prange, A.: Geochemical and structural aspects of the pycnocline in the Black Sea (R/V Knorr 134-8 Leg 1, 1988), in: Black Sea Oceanography, edited by: Izdar, E. and Murray, J. W., NATO ASI Series C, Kluwer Academic Publisher, Dordrecht, 89-110, 1991.

Kessler, J. D., Reeburgh, W. S., Southon, J., Seifert, R., Michaelis, W., and Tyler, S. C.: Basin-wide estimates of the input of methane from seeps and clathrates to the Black Sea, Earth Planet. Sc. Lett., 243, 366-375, 2006.

Labrenz, M., Jost, G., Pohl, C., Beckmann, S., Martens-Habenna, W., and Jürgens, K.: Impact of Different In Vitro Electron Donor/Acceptor Conditions on Potential Chemolithoautotrophic Communities from Marine Pelagic Redoxclines, Appl. Environ. Microb., 71, 6664-6672, 2005.

Labrenz, M., Sintes, E., Toetzke, F., Zumsteg, A., Herndl, G. J., Seidler, M., and Jürgens, K.: Relevance of a crenarchaeotal subclus- 
ter related to Candidatus Nitrosopumilus maritimus to ammonia oxidation in the suboxic zone of the central Baltic Sea, ISME J., 4, 1496-1508, 2010.

Lass, H. U. and Matthäus, W.: General oceanography of the Baltic Sea, in: State and evolution of the Baltic Sea, 1952-2005, edited by: Feistel, R., Nausch, G., and Wasmund, N., John Wiley \& Sons, Inc., New Jersey, 5-44, 2008.

Lass, H. U., Prandke, H., and Liljebladh, B.: Dissipation in the Baltic proper during winter stratification, J. Geophys. Res., 108, 3187, doi:10.1029/2002jc001401, 2003.

Ludwig, W., Strunk, O., Westram, R., Richter, L., Meier, H., Yadhukumar, Buchner, A., Lai, T., Steppi, S., Jobb, G., Forster, W., Brettske, I., Gerber, S., Ginhart, A. W., Gross, O., Grumann, S., Hermann, S., Jost, R., Konig, A., Liss, T., Lussmann, R., May, M., Nonhoff, B., Reichel, B., Strehlow, R., Stamatakis, A., Stuckmann, N., Vilbig, A., Lenke, M., Ludwig, T., Bode, A., and Schleifer, K.-H.: ARB: a software environment for sequence data, Nucl. Acids Res., 32, 1363-1371, doi:10.1093/nar/gkh293, 2004.

Makula, R. A.: Phospholipid composition of methane-utilizing bacteria, J. Bacteriol., 134, 771-777, 1978.

Matthäus, W., Nehring, D., Feistel, R., Nausch, G., Mohrholz, V., and Lass, H. U.: The inflow of high saline water into the Baltic Sea, in: State and evolution of the Baltic Sea, 1952-2005, edited by: Feistel, R., Nausch, G., and Wasmund, N., John Wiley \& Sons, Inc., New Jersey, 265-310, 2008.

Nausch, G., Nehring, D., and Nagel, K.: Nutrient concentrations, trends and their relation to eutrophication, in: State and evolution of the Baltic Sea, 1952-2005, edited by: Feistel, R., Nausch, G., and Wasmund, N., John Wiley \& Sons, Inc., New Jersey, 337366,2008

Neunlist, S. and Rohmer, M.: Novel hopanoids from the methylotrophic bacteria Methylococcus capsulatus and Methylomonas methanica, Biochem. J., 231, 635-639, 1985.

Nichols, P. D., Shaw, P. M., and Johns, R. B.: Determination of the double bond position and geometry in monoenoic fatty acids from complex microbial and environmental samples by capillary GC-MS of their Diels-Alder adducts, J. Microbiol. Meth., 3, 311-319, 1985.

Piker, L., Schmaljohann, R., and Imhoff, J. F.: Dissimilatory sulfate reduction and methane production in Gotland Deep sediments (Baltic Sea) during a transition period from oxic to anoxic bottom water (1993-1996), Aquat. Microb. Ecol., 14, 183-193, 1998.

Prokhorenko, Y. A., Krasheninnikov, B. N., Agafonov, E. A., and Basharin, V. A.: Experimental studies of the deep turbid layer in the Black Sea, Phys. Oceanogr., 5, 133-139, 1994.

Reeburgh, W. S.: Methane consumption in Cariaco Trench waters and sediments. Earth Planet. Sc. Lett., 28, 337-344, 1976.

Reeburgh, W. S.: Ocean methane biogeochemistry, Chem. Rev., 107, 486-513, 2007.

Reissmann, J. H., Burchard, H., Feistel, R., Hagen, E., Lass, H. U., Mohrholz, V., Nausch, G., Umlauf, L., and Wieczorek, G.: Vertical mixing in the Baltic Sea and consequences for eutrophication - A review, Progr. Oceanogr., 82, 47-80, 2009.

Schmale, O., Beaubien, S. E., Rehder, G., Greinert, J., and Lombardi, S.: Gas seepage in the Dnepr paleo-delta area (NW-Black Sea) and its regional impact on the water column methane cycle, J. Mar. Syst., 80, 90-100, 2010a.
Schmale, O., Schneider von Deimling, J., Gülzow, W., Nausch, G., Waniek, J. J., and Rehder, G.: Distribution of methane in the water column of the Baltic Sea, Geophys. Res. Lett., 37, L12604, doi:10.1029/2010g1043115, 2010b.

Schmale, O., Haeckel, M., and McGinnis, D. F.: Response of the Black Sea methane budget to massive short-term submarine inputs of methane, Biogeosciences, 8, 911-918, doi:10.5194/bg-8911-2011, 2011.

Schouten, S., Wakeham, S. G., and Sinninghe Damsté, J. S.: Evidence for anaerobic methane oxidation by archaea in euxinic waters of the Black Sea, Org. Geochem., 32, 1277-1281, 2001.

Schubert, C. J., Coolen, M. J. L., Neretin, L. N., Schippers, A., Abbas, B., Durisch-Kaiser, E., Wehrli, B., Hopmans, E. C., Sinninghe Damsté, J. S., Wakeham, S., and Kuypers, M. M. M.: Aerobic and anaerobic methanotrophs in the Black Sea water column, Environ. Microbiol., 8, 1844-1856, 2006.

Scranton, M. I., Crill, P., Angelis, M., Donaghay, P., and Sieburth, J.: The importance of episodic events in controlling the flux of methane from an anoxic basin, Global Biogiochem. Cy., 7, 491507, 1993.

Strady, E., Pohl, C., Yakushev, E. V., Krüger, S., and Hennings, U.: PUMP-CTD-System for trace metal sampling with a high vertical resolution. A test in the Gotland Basin, Baltic Sea, Chemosphere, 70, 1309-1319, 2008.

Summons, R. E., Jahnke, L. L., and Roksandic, Z.: Carbon isotopic fractionation in lipids from methanotrophic bacteria: Relevance for interpretation of the geochemical record of biomarkers, Geochim. Cosmochim. Ac., 58, 2853-2863, 1994.

Talbot, H. M. and Farrimond, P.: Bacterial populations recorded in diverse sedimentary biohopanoid distributions, Org. Geochem., 38, 1212-1225, 2007.

Talbot, M., Watson, D. F., Murrell, J. C., Carter, J. F., and Farrimond, P.: Analysis of intact bacteriohopanepolyols from methanotrophic bacteria by reversed-phase high-performance liquid chromatography-atmopheric pressure chemical ionisation mass spectrometry, J. Chromatogr. A, 921, 175-185, 2001.

Thießen, O., Schmidt, M., Theilen, F., Schmitt, M., and Klein, G.: Methane formation and distribution of acoustic turbidity in organic-rich surface sediments in the Arkona Basin, Baltic Sea, Cont. Shelf Res., 26, 2469-2483, 2006.

Wakeham, S. G., Amann, R., Freeman, K. H., Hopmans, E. C., Joergensen, B. B., Putnam, I. F., Schouten, S., Damste, J. S. S., Talbot, M., and Woebken, D.: Microbial ecology of the stratified water column of the Black Sea as revealed by a comprehensive biomarker study, Org. Geochem., 38, 2070-2097, 2007.

Weinbauer, M. G., Fritz, I., Wenderoth, D. F., and Höfle, M. G.: Simultaneous extraction from bacterioplankton of total RNA and DNA suitable for quantitative structure and functional analyses, Appl. Environ. Micobiol., 68, 1082-1084, 2002.

Whiticar, M. J.: Carbon and hydrogen isotope systematics of bacterial formation and oxidation of methane, Chem. Geol., 161, 291314, 1999. 